\title{
Pengaruh konsentrasi starter dan macam buah terhadap karakteristik kefir air
}

\author{
Effect of starter concentration and kinds of fruit on the characteristics of water kefir \\ Deny Utomo ${ }^{1 *}$, Tri Kurniawidi ${ }^{1)}$ \\ ${ }^{1}$ Program Studi Ilmu dan Teknologi Pangan, Fakultas Pertanian, UniversitasYudharta Pasuruan \\ *Email korespondensi: denyut369@ gmail.com
}

Informasi Artikel:

Dikirim: 03/06/2021; disetujui: 25/07/2021; diterbitkan: 28/09/2021

\begin{abstract}
Water kefir is a probiotic drink as a result of fermentation by lactobacillus acid bacteria, acetobacter and yeast. Fruits and other ingredients could be added to obtain water kefir with specific flavor and aroma. This research aims to observe the effect of starter concentration and kind of fruit used on the characteristics of water kefir, and to determine the best combination preferred by the panelists. This study used two factorial randomized design with three repetitions. The factors used are the starter concentration $(5 \%, 8 \%$, and $11 \%)$ and the kind of fruit used (snake fruit, pineapple, and papaya). Results showed that different starter concentration had an effect on brix, pH, alcohol content and density of water kefir, while different kinds of fruit had an effect on brix. Based on organoleptic test the most preferred water kefir is pineapple water kefir with 8 $\%$ starter concentration.
\end{abstract}

Key words : water kefir, starter, fruit

\begin{abstract}
ABSTRAK
Kefir air merupakan minuman probiotik yang dihasilkan dengan cara fermentasi oleh bakteri asam laktat, bakteri asam asetat dan khamir. Dalam proses pembuatannya bisa ditambahkan buah atau bahan lain untuk memperoleh kefir air dengan rasa dan aroma yang khas. Penelitian ini bertujuan untuk mengetahui pengaruh konsentrasi starter dan macam buah yang digunakan terhadap karakteristik kefir air yang dihasilkan, serta untuk mengetahui perlakuan terbaik yang paling disukai oleh panelis. Metode penelitian yang digunakan adalah rancangan acak kelompok (RAK) dua faktor dan tiga kali ulangan. Faktor perlakuan yang digunakan yaitu variasi konsentrasi starter kefir air (5\%, $8 \%$, dan $11 \%$ ) dan macam buah yang digunakan (salak, nanas, pepaya). Hasil uji kimia menunjukkan konsentrasi starter berpengaruh terhadap brix, $\mathrm{pH}$, kadar alkohol dan berat jenis kefir air. Jenis buah yang digunakan berpengaruh terhadap brix kefir air. Hasil uji organoleptik menunjukkan bahwa perlakuan yang paling disukai yaitu kefir air nanas dengan konsentrasi starter $8 \%$.
\end{abstract}

Kata kunci : kefir air, starter, buah

\section{PENDAHULUAN}

Konsumsi makanan sehat akhir-akhir ini semakin meningkat, seiring semakin meningkatnya kesadaran mengenai hidup sehat. Salah satu jenis makanan yang banyak dicari akhir-akhir ini yaitu jenis makanan probiotik, yang diyakini memiliki banyak manfaat bagi manusia. Pangan probiotik didefinisikan sebagai pangan (makanan/ minuman) yang mengandung sejumlah bakteri hidup yang memberi efek yang 
menguntungkan kesehatan (Granato et al., 2010; Yuniastuti, 2015). Schneedorf (2012) menyatakan mikroba probiotik pada umumnya adalah golongan bakteri atau jamur yang diketahui aman dikonsumsi, di antaranya berdasarkan sifat mikroba tersebut dalam memproduksi asam organik, mereduksi amina biogenik, penguraian karbohidrat dan protein, imunomodulator dan anti inflamasi, reduksi amina karsinogenik, serta produksi peptida antimikrobial.

Manfaat probiotik bagi manusia yang telah diketahui umumnya berkaitan dengan pencernaan, serta beberapa manfaat lainnya. Widiyaningsih (2011) menyatakan manfaat bakteri probiotik bagi kesehatan manusia di antaranya adalah meningkatkan sistem imunitas, membantu absorpsi nutrisi, memperpendek durasi sakit diare dan membantu pencernaan laktosa bagi penderita lactose intolerance. Tamang et al. (2010) menuliskan beberapa manfaat dari bakteri probiotik di antaranya menurunkan kadar kolesterol, amonia dan komponen beracun lain di dalam tubuh, mengembalikan mikroflora normal di dalam saluran pencernaan setelah terapi antibiotik, dan berpotensi sebagai terapi untuk penyimpangan saluran pencernaan (gastrointestinal tract disorders). Kim et al. (2010) menyatakan suplemen campuran mikroorganisme probiotik adalah pendekatan efektif dalam mencegah pertumbuhan eksim pada bayi dengan resiko alergi.

Produk probiotik yang telah cukup dikenal saat ini adalah yoghurt, yang merupakan hasil fermentasi susu oleh bakteri asam laktat. Produk fermentasi susu yang lain yaitu kefir, yang diyakini berasal dari kawasan Balkan-Kaukasia. Selain menggunakan susu, kefir juga bisa dihasilkan dari bahan baku air, air kelapa atau penambahan buah/bahan lain dan dikenal sebagai kefir air (water kefir). Produk probiotik selain susu saat ini dipandang memiliki peranan penting, mengingat tren vegetarian dan naiknya kemungkinan penderita intoleransi laktosa di seluruh dunia (Granato et al., 2010). Kefir air juga diketahui memiliki berbagai manfaat, baik dari produk minuman kefir air tersebut maupun dari starter kefir airnya (kefir grains). Alsayadi et al. (2013) menyatakan adanya aktivitas antioksidan pada kefir air, yang berasal dari adanya bakteri asam laktat, bakteri asam asetat dan khamir di dalam kefir air, sehingga disimpulkan kefir air bisa menjadi sumber antioksidan alami yang berpotensi meningkatkan kesehatan. Alsayadi et al. (2014) menyatakan manfaat kefir air bagi penderita diabetes, dimana kefir air berpotensi untuk mengontrol tingkat glukosa dan lemak bagi penderita diabetes. Sedangkan starter kefir air (kefir grains) diketahui bermanfaat sebagai sumber alami bakteri asam laktat penghasil dekstran, dan layak untuk dikembangkan secara komersial (Davidović et al., 2015). Volpi et al. (2019) menyimpulkan terdapat potensi starter kefir air untuk pemurnian air yang tercemar ion logam berat secara aman dan efektif.

Lestari, Bintoro dan Rizqiati (2018) menyatakan kefir air adalah jenis kefir yang dibuat dari bahan dasar berupa cairan yang mengandung gula seperti sari buah, air kelapa, dan air gula yang kemudian ditambah butiran/starter kefir sehingga dapat menghasilkan minuman probiotik yang asam dan mengandung sedikit alkohol dari proses fermentasi. Schneedorf (2012) menuliskan bahwa kefir air atau kefir d'aqua, atau sugary kefir merupakan minuman fermentasi buatan rumah tangga yang dibuat dari larutan gula (sukrosa) dengan atau tanpa penambahan sari buah. Penampakan visual dari kefir air yaitu berupa cairan sedikit keruh, dengan rasa yang asam, sedikit manis, dengan sedikit kandungan alkohol dan karbondioksida sebagai hasil fermentasi.

Kefir susu dan kefir air termasuk dalam probiotik meskipun memiliki strain bakteri yang berbeda. Menurut Schneedorf (2012), strain mikroba pada kefir susu lebih banyak daripada mikroba pada kefir air. Beberapa penelitian mengungkapkan bahwa konsorsium mikroba yang aktif pada fermentasi kefir air terdiri atas kelompok bakteri asam laktat, bakteri asam asetat, bakteri penghasil etanol, bifidobacteria, dan 
khamir (Gulitz et al., 2011; Marsh et al., 2013; Diosma et al., 2014.).

Beberapa penelitian telah dilakukan berkaitan dengan pembuatan kefir air dengan menggunakan berbagai bahan, baik sari buah maupun larutan lain, di antaranya penggunaan nira siwalan, buah strawberry, dan daun kersen. Mubin dan Zubaidah (2016) melakukan penelitian untuk mencari kombinasi pengenceran nira dan metode inkubasi terbaik untuk mendapatkan parameter kimia, fisik serta mikrobiologi terbaik pada pembuatan kefir nira siwalan. Lathif (2016) menyatakan ada pengaruh antara interaksi konsentrasi daun kersen (Muntingia calabura L.) dan lama fermentasi terhadap total asam, $\mathrm{pH}$, dan aktivitas antioksidan pada kefir teh daun kersen. Randazzo et al. (2016) menyimpulkan penggunaan apel dan anggur lebih disukai para penguji dalam pembuatan kefir air dengan variasi buah. Puerari, Magalhães dan Schwan (2012) menyimpulkan berdasarkan karakteristik kimia dan penerimaan analisa sensori, terbuka kemungkinan untuk pengembangan minuman kefir berbahan dasar daging buah kakao (Theobroma cacao L.).

Konsentrasi bibit kefir yang ditambahkan diduga mempengaruhi jalannya proses fermentasi. Beberapa penelitian menggunakan konsentrasi bibit kefir sebanyak $5 \%$ untuk pembuatan kefir air (Muizuddin dan Zubaidah, 2015; Lestari et al., 2018). Rahmah (2016) menuliskan penggunaan starter $6 \%$ untuk meneliti pengaruh jenis gula merah dan lama fermentasi terhadap karakteristik kefir air. Menurut Angela (2016) perlakuan terbaik adalah konsentrasi starter $8 \%$ pada kefir strawberry yang berpengaruh nyata terhadap sifat kimia (warna dan $\mathrm{pH}$ ) dan organoleptik (warna, rasa dan aroma). Berdasarkan beberapa penelitian tersebut pada penelitian kali ini digunakan variasi konsentrasi starter 5, 8 dan $11 \%$ serta variasi buah nanas, salak dan pepaya.

Penelitian ini bertujuan untuk :

1. Mengetahui konsentrasi starter kefir dan jenis buah yang sesuai digunakan dalam proses pembuatan kefir air dan pengaruhnya terhadap karakteristik kefir air yang dihasilkan.

2. Mendapatkan kombinasi perlakuan terbaik dari konsentrasi starter dan macam buah yang digunakan dalam proses pembuatan kefir air, ditinjau dari sisi parameter fisiko kimia.

3. Mendapatkan kombinasi perlakuan terbaik dari konsentrasi starter dan macam buah yang digunakan dalam proses pembuatan kefir air, ditinjau dari segi organoleptik.

\section{METODE}

\section{Bahan}

Bahan untuk pembuatan kefir air adalah bibit/starter kefir air yang diperoleh dari Mojokerto, kismis kering diperoleh dari toko kue di Pandaan, buah-buahan (nanas, salak dan pepaya) dan gula pasir yang diperoleh dari Pasar Pandaan - Pasuruan. Mikroba aktif dalam starter kefir air yang digunakan yaitu Lactobacillus hilgardii, Lactobacillus casei dan Saccharomyces cerevisiae.

\section{Alat}

Alat untuk pembuatan kefir air adalah toples plastik, sendok plastik, timbangan digital, blender, saringan, gelas ukur, lemari es, panci, kompor. Alat yang digunakan untuk analisa adalah beaker glass, erlenmeyer, neraca analitik, hot plate, labu destilasi, kondensor, piknometer, gelas ukur, pipet ukur, pipet tetes, $\mathrm{pH}$ meter, refraktometer, viscotester, thermometer, corong, kertas label, kapas, tissue.

\section{Metode/pelaksanaan}

Penelitian dilakukan di laboratorium

Ilmu dan Teknologi Pangan Universitas Yudharta Pasuruan pada bulan April - Juli 2020.

Metode yang digunakan dalam penelitian ini adalah Rancangan Acak Kelompok (RAK) dengan 2 faktor. Faktor pertama yaitu konsentrasi starter $(5,8$, dan $11 \%$ ), faktor ke dua yaitu jenis buah (salak, nanas, dan pepaya). Terdapat 9 kombinasi perlakuan dan masing masing perlakuan 
dilakukan 3 kali pengulangan. Data yang diperoleh dari hasil penelitian dianalisis secara deskriptif dari data rata-rata ulangan setiap parameter. Perlakuan terbaik dipilih berdasarkan hasil uji sesuai parameter pengujian. Data pengamatan hasil analisa kimia dilakukan pengolahan data dengan analisa variansi (anova) pada taraf perbedaan $5 \%(\alpha=0,05)$. Parameter yang dianalisa yaitu $\mathrm{pH}$, brix, viskositas, berat jenis dan kadar alkohol. Analisis organoleptik dilakukan tehadap rasa, aroma dan warna pada masing-masing perlakukan menggunakan metode Hedonic Test dengan skala nilai 1-5. Semakin tinggi nilai yang diberikan maka semakin tinggi pula tingkat kesukaan konsumen.

Hasil dari pengujian organoleptik oleh para panelis dianalisa dengan uji Friedman pada taraf signifikansi $5 \%$ untuk mengetahui adanya perbedaan antara sampel. Untuk menentukan kombinasi perlakuan terbaik dilakukan dengan uji Efektifitas sehingga bisa diketahui kombinasi perlakuan terbaik sesuai preferensi panelis.

Pembuatan kefir air dilakukan menggunakan peralatan berbahan plastik atau kaca untuk menghindari reaksi antara kefir dengan permukaan peralatan. Bibit kefir air dibilas dengan air mengalir dan ditiriskan, penimbangan bibit kefir dilakukan dalam kondisi air bilasan telah tiris. Buahbuahan yang akan digunakan dikupas dan dicuci, kemudian dipotong-potong berukuran $0,5-1 \mathrm{~cm}$ agar nantinya memudahkan proses penimbangan dan penghalusan. Gula pasir dan kismis yang akan digunakan juga disiapkan dan ditimbang sesuai takaran. Komposisi bahan yang digunakan yaitu gula pasir $85 \mathrm{~g} / \mathrm{l}$, kismis $15 \mathrm{~g} / \mathrm{l}$ dan potongan buah $50 \mathrm{~g} / \mathrm{l}$.

Potongan buah dihaluskan menggunakan blender dengan ditambah gula sesuai takaran dan air $80 \%$ dari volume. Jus buah kemudian disaring untuk memperoleh sari buahnya. Sari buah yang dihasilkan kemudian ditambah air sampai dengan $100 \%$ volume dan dipasteurisasi pada suhu $75^{\circ} \mathrm{C}$ selama 5 menit. Sari buah yang telah dipasteurisasi didinginkan hingga suhu < $30^{\circ} \mathrm{C}$ atau hingga suhu ruang, kemudian ditambahkan kismis dan bibit kefir sesuai perlakuan. Proses fermentasi dilakukan pada suhu ruangan (ambient) selama 24 jam. Setelah waktu fermentasi tercapai, hasil fermentasi disaring dan filtrat yang dihasilkan diamati. Bibit kefir dibilas dengan air untuk disimpan.

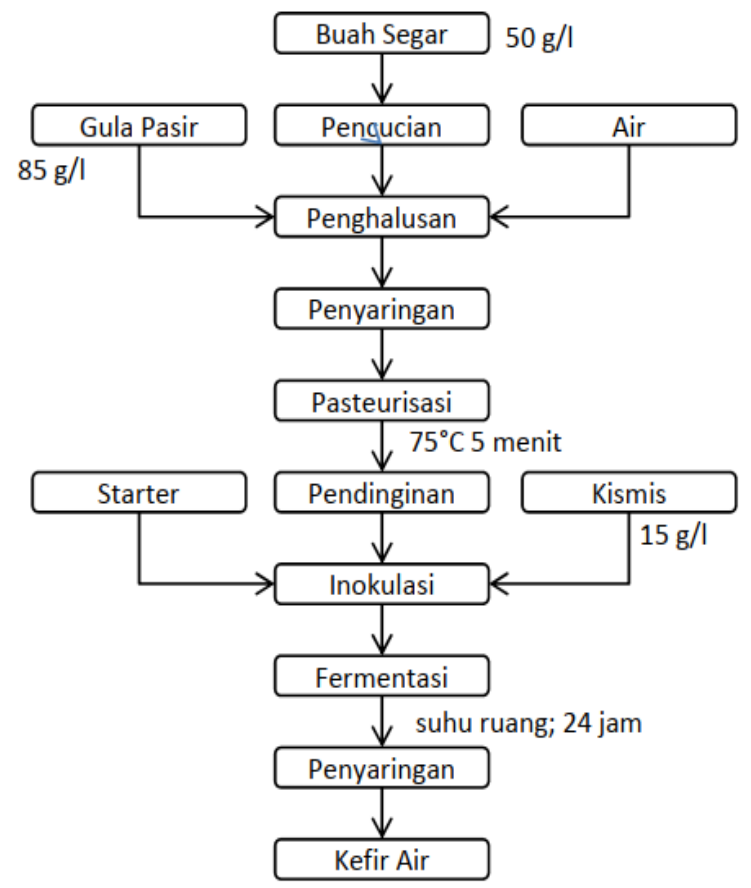

Gambar 1. diagram alir pengolahan kefir air

\section{HASIL DAN PEMBAHASAN}

\section{Brix}

Dari hasil fermentasi diperoleh data bahwa kefir air dengan konsentrasi starter yang lebih rendah mempunyai brix yang lebih tinggi. Hasil anova terhadap data brix menunjukkan bahwa ada beda nyata antara kefir air dengan variasi penambahan starter maupun variasi jenis buah.

Perbedaan konsentrasi starter yang ditambahkan berarti pula ada perbedaan jumlah mikroba yang ditambahkan, sehingga akan mempengaruhi jalannya fermentasi. Pada perlakuan dengan konsentrasi starter paling rendah (5\%) jumlah mikroba aktif lebih sedikit, sehingga fermentasi akan berjalan lebih lambat. Menurut Mubin dan Zubaidah (2016) aktifitas mikroba pada produk bisa diketahui dari berkurangnya 
kadar gula dalam sampel, dimana kultur yang tumbuh dengan optimal mampu bermultiplikasi dengan baik dan membutuhkan lebih banyak gula untuk dirombak sehingga gula yang tersisa pada produk semakin sedikit. Hal sebaliknya berlaku untuk kefir air dengan konsentrasi starter yang lebih kecil, dimana jumlah gula yang bisa diuraikan oleh mikroba akan lebih sedikit, sehingga pada akhir proses fermentasi masih terdapat sisa gula yang lebih banyak yang bisa diketahui dari brix yang lebih tinggi dibandingkan pada perlakuan dengan konsentrasi starter yang lebih tinggi.

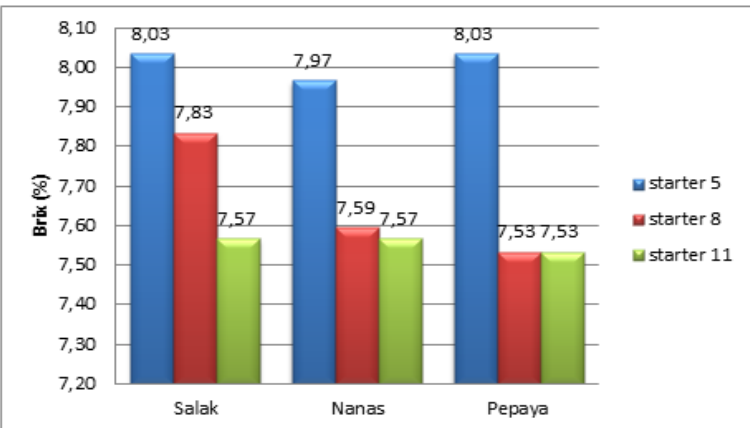

Gambar 2. Diagram brix kefir air

Sedangkan perbedaan jenis buah akan berpengaruh terhadap kandungan gula awal sebelum proses fermentasi berlangsung, baik kadarnya maupun jenis gula yang terkandung dalam masing-masing buah (glukosa, fruktosa). Gula yang terdapat dalam larutan merupakan substrat yang akan diuraikan mikroba selama proses fermentasi, sehingga adanya perbedaan kandungan gula awal akan berpengaruh pula terhadap jalannya proses fermentasi. Menurut Gunawan et al. (2013) adanya penambahan substrat menyebabkan berlimpahnya nutrisi di dalam larutan sehingga aktivitas mikroorganisme akan semakin meningkat. Adanya penambahan buah dan juga kismis diduga mempengaruhi aktifitas mikroorganisme selama fermentasi, sehingga akan menghasilkan brix pada kefir air yang bervariasi.

\section{pH}

Pengamatan terhadap $\mathrm{pH}$ kefir air yang dihasilkan menunjukkan bahwa semakin tinggi konsentrasi bibit kefir yang digunakan dalam proses fermentasi, maka larutan kefir air yang dihasilkan akan semakin asam. Hal ini ditunjukkan pada ketiga variasi buah yang digunakan. Hasil anova juga menunjukkan ada korelasi antara konsentrasi starter yang digunakan terhadap $\mathrm{pH}$ kefir air yang dihasilkan. Sedangkan pada variasi jenis buah tidak ada beda nyata pada kefir air yang dihasilkan.

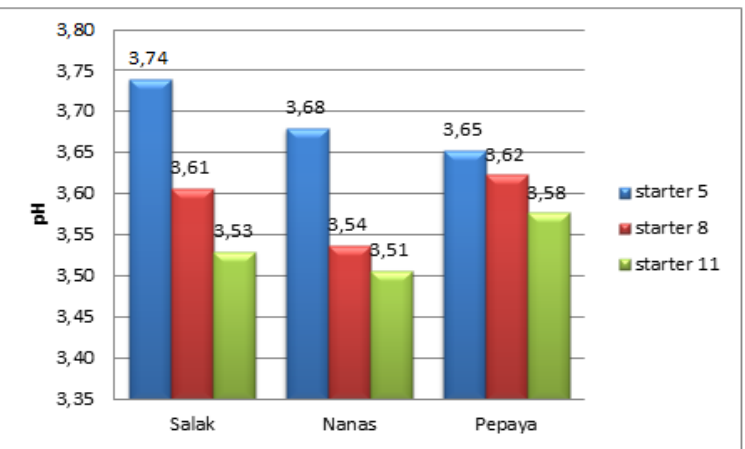

Gambar 3. Diagram pH kefir air

Pada fermentasi dengan konsentrasi starter lebih tinggi diperoleh kefir air yang lebih asam. Hal ini terjadi karena dengan penambahan starter berarti terdapat lebih banyak mikroba yang akan melakukan fermentasi, sehingga proses fermentasi akan berjalan lebih cepat dan asam laktat yang terbentuk akan semakin banyak sehingga meningkatkan tingkat keasaman kefir yang dihasilkan. Hasil penelitian ini sesuai dengan penelitian oleh Angela (2016) yang menyimpulkan semakin tinggi konsentrasi starter maka $\mathrm{pH}$ akan semakin rendah.

\section{Kadar alkohol}

Dari hasil analisa kadar alkohol, diketahui kandungan alkohol lebih tinggi terdapat pada kefir air dengan penambahan starter yang lebih banyak. Hal ini sesuai dengan yang dituliskan Prajapati dan Nair (2008) yang menyatakan kadar alkohol dalam kefir air ditentukan oleh banyaknya khamir yang terdapat di dalam starter yang ditambahkan dan lamanya fermentasi.

Dari hasil anova juga terlihat korelasi antara konsentrasi starter yang ditambahkan terhadap kadar alkohol kefir air. Kandungan alkohol pada kefir air berbanding lurus dengan jumlah starter yang ditambahkan, semakin banyak starter yang ditambahkan maka kadar alkohol akan semakin tinggi. Hal 
ini terjadi karena dengan penambahan jumlah starter maka akan semakin banyak mikroba aktif yang tersedia, sehingga laju fermentasi meningkat yang secara langsung akan meningkatkan jumlah alkohol yang dihasilkan. Adanya perbedaan kandungan jenis gula juga diduga bisa menghasilkan perbedaan kadar alkohol (Rahmah, 2016), sehingga adanya variasi kandungan gula dalam buah yang ditambahkan juga bisa mempengaruhi kadar alkohol pada kefir air.

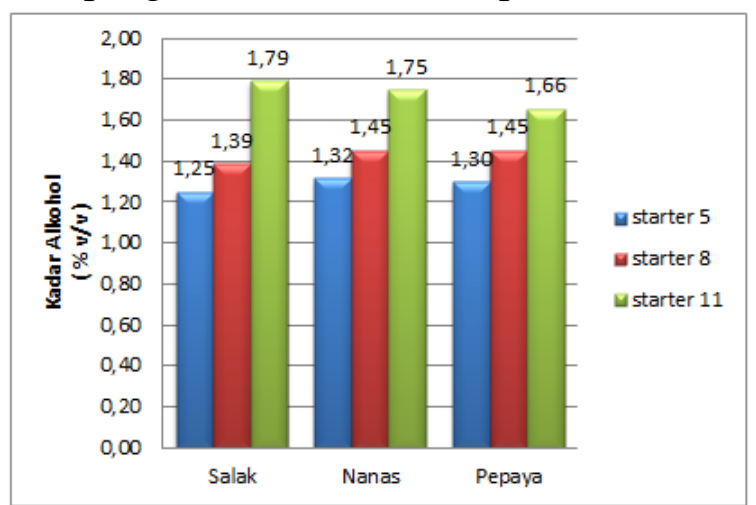

Gambar 4. Diagram kadar alkohol kefir air

\section{Berat Jenis}

Berat jenis kefir air berada di kisaran 1.0341 hingga 1.0369 , dengan range berat jenis yang lebih bervariasi pada kefir air pepaya dimana berat jenisnya berkisar antara 1.0341 hingga 1.0366. Dari hasil anova dapat disimpulkan bahwa terdapat beda nyata pada parameter berat jenis dengan variasi konsentrasi starter.

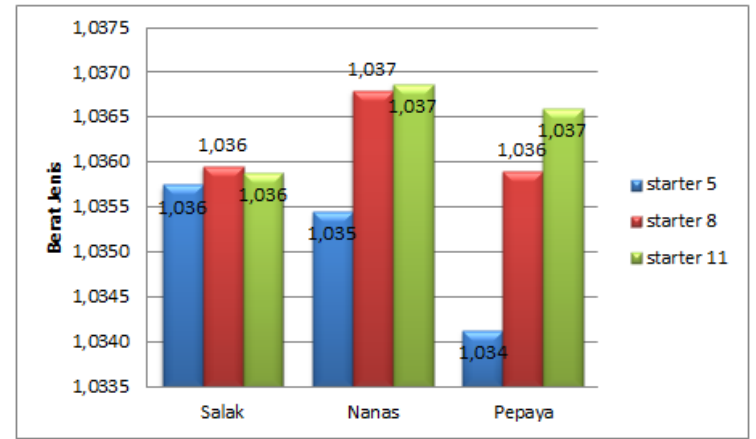

Gambar 5. Diagram berat jenis kefir air

Randazzo et al. (2016) menyatakan bahwa aktifitas Lactobacillus akan meningkatkan konsistensi kefir air, dan pada akhirnya berpengaruh terhadap berat jenisnya. Peningkatan aktifitas mikroba akibat dari penambahan starter akan meningkatkan produksi metabolit, dan akan berpengaruh terhadap berat jenis larutan.

\section{Uji organoleptik}

Pengujian organoleptik dilakukan melalui uji hedonik dengan 25 orang panelis tidak terlatih meliputi rasa, aroma dan warna dari kefir air, dengan skala penilaian $1-5$ yaitu (1) tidak suka, (2) kurang suka, (3) biasa, (4) suka, dan (5) sangat suka. Hasil uji organoleptik rasa kefir air menunjukkan sampel yang lebih disukai rasa dan aromanya adalah kefir nanas untuk semua konsentrasi starter yang dipakai.

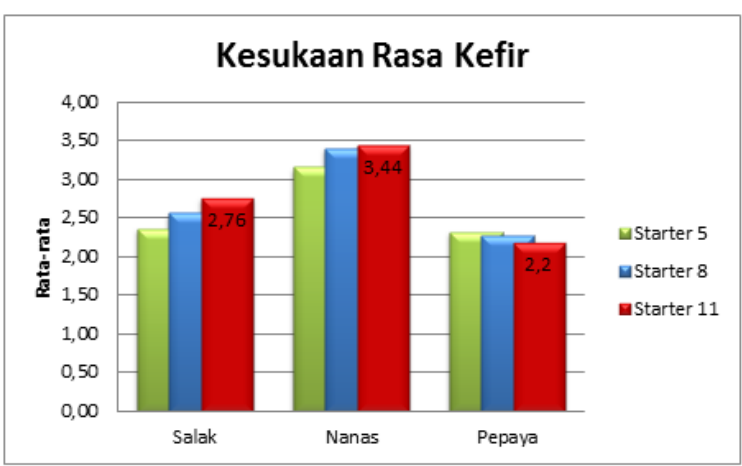

Gambar 6. Diagram kesukaan rasa kefir air

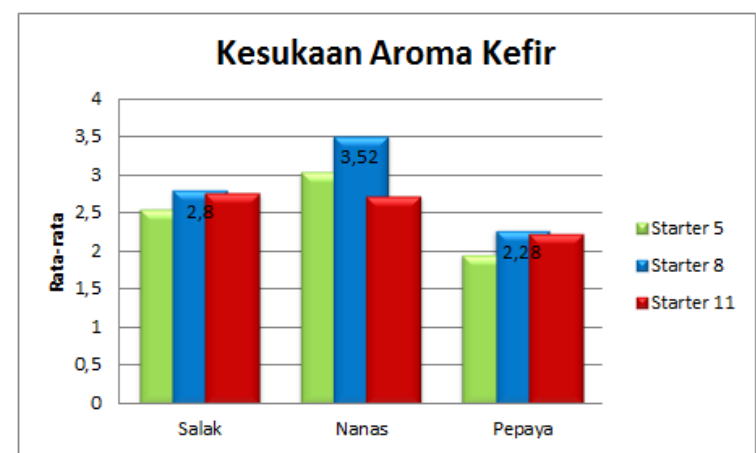

Gambar 7. Diagram kesukaan aroma kefir air

Rasa dan aroma kefir air nanas cenderung lebih disukai karena rasa dan aroma nanas tersebut lebih menonjol dibanding buah lain. Rasa dan aroma buah salak dan pepaya akan menurun seiring berjalannya fermentasi, dan kurang begitu terasa pada kefir air yang dihasilkan.

Penilaian panelis terhadap warna kefir menunjukkan warna kefir air salak lebih disukai, dan warna kefir air nanas lebih tidak disukai. Kefir air salak warna lebih terlihat cerah dibandingkan kefir nanas maupun 
pepaya, sehingga lebih disukai. Kefir air dengan penambahan starter yang lebih sedikit juga cenderung lebih disukai. Penambahan starter yang lebih sedikit berarti akan lebih sedikit aktifitas mikroba, sehingga perubahan warna larutan lebih minimal dan lebih disukai panelis dibandingkan warna kefir air dengan konsentrasi starter tinggi yang cenderung berwarna lebih keruh.

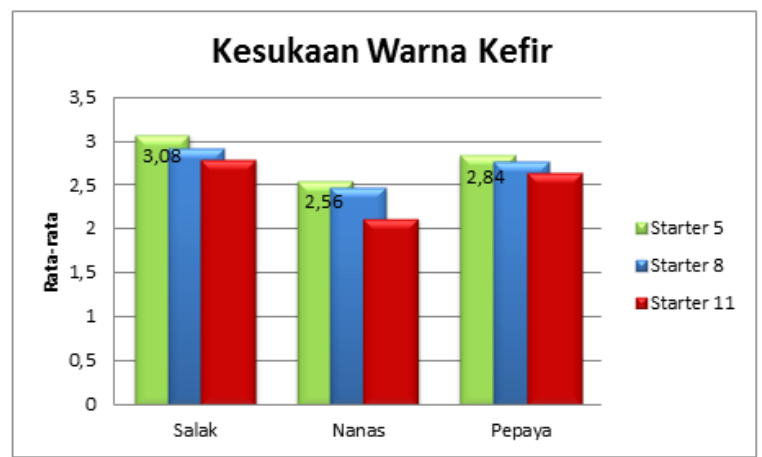

Gambar 8. Diagram kesukaan warna kefir air

Hasil uji Friedman $(\alpha: 0,05)$ untuk ketiga parameter rasa, aroma dan rasa menunjukkan $\mathrm{X}_{\text {hitung }}$ yang lebih besar dari pada $X_{\text {tabel }}$. $X_{\text {hitung }}$ untuk rasa, aroma dan rasa kefir air berturut-turut 67,$43 ; 32,14$; dan 42,01 lebih besar dari pada $\mathrm{X}_{\text {tabel }}$ sebesar 15,51 sehingga dapat disimpulkan ada perbedaan nyata dalam hal rasa, aroma dan rasa dari kefir air dengan 9 macam perlakuan tersebut.

\section{Uji efektifitas}

Dari hasil uji efektifitas dapat disimpulkan bahwa perlakuan kefir air yang paling disukai adalah dengan penambahan sari buah nanas dan penambahan starter kefir $8 \%$ dengan hasil indeks tertinggi sebesar 0,85 . Secara visual (warna) kefir nanas kurang disukai, namun secara keseluruhan kefir nanas lebih disukai.

Hal ini dipengaruhi oleh preferensi panelis yang menitikberatkan penilaian kesukaan kefir air pada parameter rasa dan aroma, sehingga kefir nanas yang memiliki rasa dan aroma yang lebih kuat lebih disukai dibandingkan kefir salak maupun pepaya. Sedangkan konsentrasi $8 \%$ lebih dipilih karena merupakan perpaduan yang pas dan seimbang antara rasa dan aroma buah dengan kombinasi soda dan alkohol.

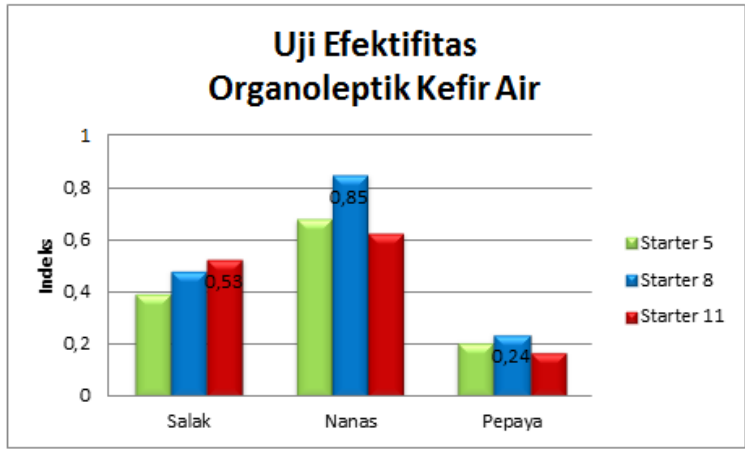

Gambar 9. Uji efektifitas kefir air

\section{KESIMPULAN}

Dari hasil penelitian yang telah dilakukan dapat disimpulkan bahwa

1. Konsentrasi starter kefir yang digunakan berpengaruh terhadap $\mathrm{pH}$, brix, kadar alkohol dan berat jenis kefir air yang dihasilkan.

2. Jenis buah yang digunakan berpengaruh terhadap brix kefir air yang dihasilkan.

3. Kombinasi perlakuan terbaik untuk pembuatan kefir air adalah dengan menggunakan sari buah nanas dengan penambahan starter kefir air $8 \%$. Parameter fisiko kimia perlakuan terpilih yaitu brix $7.59 \%, \mathrm{pH} 3.54$, berat jenis 1.0368 dan kadar alkohol $1.45 \%$.

\section{DAFTAR PUSTAKA}

Alsayadi, M., Jawfi, Y. Al, Belarbi, M., \& Sabri, F. (2013). Antioxidant potency of water kefir. Journal of Microbiology, Biotechnology and Food Sciences, 2(6), 2444-2447.

Alsayadi, M., Jawfi, Y. Al, Belarbi, M., Soualem-Mami, Z., Merzouk, H., Sari, D. C., ... Ghalim, M. (2014). Evaluation of anti-hyperglycemic and anti-hyperlipidemic activities of water kefir as probiotic on streptozotocininduced diabetic wistar rats. Journal of Diabetes Mellitus, 04(02), 85-95. https://doi.org/10.4236/jdm.2014.42015

Angela, S. (2016). Pengaruh konsentrasi starter terhadap sifat fisikokimia dan organoleptik kefir strawberry (fragaria sp) [Skripsi]. Universitas Katolik Widya 
Mandala Surabaya.

Davidović, S. Z., Miljković, M. G., Antonović, D. G., Rajilić-Stojanović, M. D., \& Dimitrijević-Branković, S. I. (2015). Water kefir grain as a source of potent dextran producing lactic acid bacteria. Hemijska Industrija, 69(6), 595-604.

https://doi.org/10.2298/HEMIND14092 5083D

Diosma, G., Romanin, D. E., Rey-Burusco, M. F., Londero, A., \& Garrote, G. L. (2014). Yeasts from kefir grains: isolation, identification, and probiotic characterization. World Journal of Microbiology and Biotechnology, 30(1), 43-53. https://doi.org/10.1007/s11274013-1419-9

Granato, D., Branco, G. F., Nazzaro, F., Cruz, A. G., \& Faria, J. A. F. (2010). Functional foods and nondairy probiotic food development: trends, concepts, and products. Comprehensive Reviews in Food Science and Food Safety, 9(3), 292-302.

https://doi.org/10.1111/j.15414337.2010.00110.x

Gulitz, A., Stadie, J., Wenning, M., Ehrmann, M. A., \& Vogel, R. F. (2011). The microbial diversity of water kefir. International Journal of Food Microbiology, 151(3), 284-288. https://doi.org/10.1016/j.ijfoodmicro.20 11.09.016

Gunawan, G. A., Atmodjo, P. K., \& Sidharta, B. B. R. (2013). Variasi kismis dan sukrosa terhadap pertumbuhan asam laktat dan alkohol kristal alga. Teknologi Pangan, 1-14.

Kim, J. Y., Kwon, J. H., Ahn, S. H., Lee, S. Il, Han, Y. S., Choi, Y. O., ... Ji, G. E. (2010). Effect of probiotic mix (bifidobacterium bifidum, bifidobacterium lactis, lactobacillus acidophilus) in the primary prevention of eczema: a double-blind, randomized, placebo-controlled trial. Pediatric Allergy and Immunology, 21(2 PART 2), 1-8. https://doi.org/10.1111/j.13993038.2009.00958.x
Lathif, Y. (2016). Pengaruh lama fermentasi dan variasi konsentrasi daun kersen (muntingia calabura l.) terhadap total asam, $p H$ medium dan aktivitas antioksidan kefir air teh daun kersen [Skripsi]. Universitas Islam Negeri Maulana Malik Ibrahim Malang.

Lestari, M. W., Bintoro, V. P., \& Rizqiati, H. (2018). Pengaruh lama fermentasi terhadap tingkat keasaman, viskositas, kadar alkohol, dan mutu hedonik kefir air kelapa. Jurnal Teknologi Pangan, 2(1), 8-13.

Marsh, A. J., O'Sullivan, O., Hill, C., Ross, R. P., \& Cotter, P. D. (2013). Sequencebased analysis of the microbial composition of water kefir from multiple sources. FEMS Microbiology Letters, 348(1), 79-85. https://doi.org/10.1111/15746968.12248

Mubin, M. F., \& Zubaidah, E. (2016). Studi pembuatan kefir nira siwalan (borassus flabellifer 1.) pengaruh pengenceran nira siwalan dan metode inkubasi. Jurnal Pangan Dan Agroindustri, 4(1), 291301.

Muizuddin, M., \& Zubaidah, E. (2015). Studi aktivitas antibakteri kefir teh daun sirsak (annona muricata linn .) dari berbagai merk teh daun sirsak di pasaran. Jurnal Pangan Dan Agroindustri, 3(4), 1662-1672.

Prajapati, J. B., \& Nair, B. M. (2008). The history of fermented foods. In E. Farnworth (Ed.), Handbook of Fermented Functional Foods, Second Edition (2nd ed.). Boca Raton: CRC Press.

https://doi.org/10.1201/9780203009727. ch1

Puerari, C., Magalhães, K. T., \& Schwan, R. F. (2012). New cocoa pulp-based kefir beverages: microbiological, chemical composition and sensory analysis. Food Research International, 48(2), 634-640. https://doi.org/10.1016/j.foodres.2012.0 6.005

Rahmah, F. A. (2016). Pengaruh penggunaan jenis gula merah dan lama 
fermentasi terhadap karakteristik water kefir [Skripsi]. Universitas Pasundan Bandung.

Randazzo, W., Corona, O., Guarcello, R., Francesca, N., Germanà, M. A., Erten, H., ... Settanni, L. (2016). Development of new non-dairy beverages from mediterranean fruit juices fermented with water kefir microorganisms. Food Microbiology, 54, 40-51. https://doi.org/10.1016/j.fm.2015.10.01 8

Schneedorf, J. M. (2012). Kefir d'aqua and its probiotic properties. In Probiotic in Animals (pp. 53-76). https://doi.org/http://dx.doi.org/10.5772 150053

Tamang, J. P., Adams, M., Aidoo, K. E., Alegria, A., Ammor, M. S., Ban-Koffi, L., ... Wacher, C. (2010). Fermented foods and beverages of the world (1st ed.; J. P. Tamang \& K. Kailasapathy, Eds.). Boca Raton: CRC Press. https://doi.org/10.16309/j.cnki.issn.100 7-1776.2003.03.004

Volpi, G., Ginepro, M., Tafur-Marinos, J., Zelano, V., \& Goulas, V. (2019). Pollution abatement of heavy metals in different conditions by water kefir grains as a protective tool against toxicity. Journal of Chemistry, 2019, 27-30.

https://doi.org/10.1155/2019/8763902

Widiyaningsih, E. N. (2011). Peran probiotik untuk kesehatan. Jurnal Kesehatan, 4(1), 14-20.

Yuniastuti, A. (2015). Buku monograf probiotik (dalam perspektif kesehatan). Semarang: Unnes Press. https://doi.org/10.1017/CBO978110741 5324.004 